\title{
Avaliação do efeito das concentrações de sacarose e dos estádios de desenvolvimento do fruto no cultivo in vitro de embriões de frutos de cafeeiro
}

\author{
Adriana Madeira Santos Jesus ${ }^{1}$, Fabíola Villa ${ }^{2}$, Ana Carolina da Costa Lara ${ }^{3}$, Moacir Pasqual $^{4}$
}

\section{RESUMO}

A cultura in vitro é uma técnica controlada que proporciona estudar os processos nutricionais, fisiológicos e bioquímicos de embriões em vários estádios de desenvolvimento. O objetivo foi avaliar a relação entre estádio de desenvolvimento do fruto e concentração de sacarose, no meio, durante o desenvolvimento, in vitro, de embriões de cafeeiro. Frutos de Coffea arabica cv. Acaiá foram colhidos, lavados, desinfestados, seus embriões excisados e inoculados em meio de cultivo MS, com pH ajustado para 5,8. Os tratamentos consistiram em combinação de concentrações de sacarose $\left(0,15,30,60,90\right.$ e $\left.120 \mathrm{~g} \mathrm{~L}^{-1}\right)$ e estádios de desenvolvimento do fruto (chumbinho, chumbo, verde, verde-cana, cereja e passa). Após a inoculação, os embriões foram incubados em sala de crescimento, a $27 \pm 1{ }^{\circ} \mathrm{C}$, fotoperíodo de 16 horas e $35 \mu \mathrm{mol} \mathrm{m} \mathrm{m}^{-1}$ de intensidade luminosa. O delineamento experimental utilizado foi inteiramente casualizado, em esquema fatorial 6 x 6, com seis repetições constituídas por quatro tubos cada. Após 60 dias de desenvolvimento, as plântulas foram avaliadas com base no comprimento da parte aérea, massa de matéria fresca total da parte aérea e das raízes. Observaram-se influências das concentrações de sacarose e dos estádios de desenvolvimento do fruto no crescimento e desenvolvimento das plântulas. Resultados satisfatórios para todas as variáveis estudadas foram obtidos com embriões excisados no estádio verde, inoculados em meio de cultivo suplementado com 51 a $70 \mathrm{~g} \mathrm{~L}^{-1}$ de sacarose.

Palavras-chave: Coffea arabica L., cultura de embriões, concentração de sacarose, estádios de desenvolvimento do fruto.

\section{ABSTRACT \\ Evaluation of the effects of sucrose concentrations and stages of fruit development in the in vitro embryos culture of coffee fruits}

In vitro culture offers a controlled system to study the nutritional, physiologic and biochemical processes of embryos in several developmental stages. In this work, the relationship between development stage of the fruit and sucrose concentration in the culture medium for in vitro development of coffee embryos was evaluated. Embryos of Coffea arabica L. cv. Acaiá were excised and inoculated into the culture medium MS with pH adjusted to 5.8. The treatments consisted of the combination of six sucrose concentrations $\left(0,15,30,60,90\right.$ and $\left.120 \mathrm{~g} \mathrm{~L}^{-1}\right)$ and six developmental stages of the fruit ('pin-head', 'lead', 'green', 'green-yellow', 'cherry' and 'overripe'). After inoculation, the embryos were incubated in growth room at $27 \pm 1^{\circ} \mathrm{C}$, photoperiod of 16 hours and $35 \mathrm{ì} \mathrm{mol} \mathrm{m} \mathrm{m}^{-2} \mathrm{~s}^{-1}$ of luminous

Received 05/01/2011 and accepted for publication 21/10/2011

'Engenheira-Agrônoma, Doutora. Pesquisadora da Unidade Regional da Empresa de Pesquisa Agropecuária de Minas Gerais (EPAMIG), Caixa Postal 351, 38001-970, Uberaba, Minas Gerais, Brasil. adriana.madeira@epamig.br

${ }^{2}$ Engenheira-Agrônoma, Doutora. Pós-doutoranda EPAMIG/FAPEMIG, 37517-000, Maria da Fé, Minas Gerais, Brasil. fvilla2003@libero.it

${ }^{3}$ Engenheira-Agrônoma. Mestranda em Produção Vegetal, Universidade Estadual de São Paulo (FCAV-UNESP), 14884-900, Jaboticabal, São Paulo, Brasil. anacostlara@ gmail.com ${ }^{4}$ Engenheiro-Agrônomo, Doutor. Departamento de Agricultura (DAG), Campus Universitário, Universidade Federal de Lavras (UFLA), Campus Universitário, 37517-000, Lavras, Minas Gerais, Brasil. mpasqual@ufla.br 
intensity. The experimental design was entirely randomized ( 6 x 6 factorial), with six repetitions and the parcel constituted by four tubes each. After 60 days, the seedlings were evaluated based on shoot length, total fresh weight of shoot and root. Influences of the sucrose concentrations and the stages of fruit development were observed, and the best results were obtained with embryos excised in the stage 'green' and inoculated in the culture medium supplemented with 51 to $70 \mathrm{~g}$ sucrose $\mathrm{L}^{-1}$.

Key words: Coffea arabica L., culture of embryos, sucrose concentration, stages of fruit development.

\section{INTRODUÇÃO}

O Brasil é o maior produtor mundial de café e oferece aos mercados nacional e internacional os cafés mais saborosos do mundo. O sucesso dessa atividade deve-se em grande parte ao trabalho de produtores rurais de base familiar. A cafeicultura brasileira é representada por 300 mil propriedades de tamanhos diversos, sendo $2 / 3$ de pequenos produtores, que produzem dentro de normas e critérios de sustentabilidade social, ambiental e econômica, e que empregam 8,4 milhões de trabalhadores, gerando um valor bruto, na produção, de US $\$ 5$ bilhões (Revista Cafeicultura, 2007).

A cultura de embriões pode ser utilizada para o desenvolvimento de híbridos, interespecíficos ou intergenéticos, que não sobrevivem naturalmente. A técnica oferece um sistema controlado para estudar os processos nutricionais, fisiológicos e bioquímicos dos embriões em vários estádios de desenvolvimento (Pasqual \& Pinto, 1988). A regeneração de plantas, a partir de cultura de embriões imaturos ou maduros, já foi descrita para várias espécies de importância econômica (Paterson \& Everett, 1985; Krasnyanski et al., 1992), com alta eficiência para algumas e baixa para outras, sendo motivo de constantes estudos. Vários autores descrevem como promissora a cultura de embriões de cafeeiro in vitro; porém, ainda não se pode determinar qual estádio de desenvolvimento do fruto é o mais eficiente (Pereira et al., 2007; Rezende et al., 2008a, Rezende et al., 2008b).

Os embriões são usualmente cultivados com sucesso em meio de cultura, que consiste em sais, geralmente, do MS (Murashige \& Skoog, 1962) e carboidratos, meio esse solidificado com ágar. Mas, ao contrário, embriões excisados imaturos requerem nutrição mais completa (Santos et al., 2005). Os carboidratos promovem o crescimento das raízes ou dos primórdios radiculares e foliares e desempenham um papel importante na manutenção da osmolaridade apropriada, no meio de cultura (Pasqual et al., 2001). A sacarose é a fonte de energia mais comumente utilizada nos meios nutritivos, suportando as mais altas taxas de crescimento, na maioria das culturas.
O estádio de desenvolvimento em que os frutos são colhidos também influencia na cultura de embriões, visto que, quanto mais jovens os embriões, mais difícil é o seu cultivo in vitro, tanto por seu pequeno tamanho e danos durante a excisão, quanto pelas exigências nutricionais mais complexas. Assim, quanto mais jovens os embriões, tanto maior será a osmolaridade requerida para o meio, o que pode ser obtido via aumento da concentração de sacarose (Pasqual et al., 2001).

Ribeiro et al. (2003) estudaram o efeito de diferentes concentrações de sacarose no desenvolvimento in vitro de embriões de laranjeira 'Pêra', observando maior comprimento da parte áerea em meio MS, com $60 \mathrm{~g} \mathrm{~L}^{-1}$. Caso haja deficiência de sacarose no meio nutritivo, ocorre a formação de plântulas disformes, com baixa probabilidade de sobrevivência, ou a ausência de germinação dos embriões.

Geralmente não se usam reguladores de crescimento, como auxinas e citocininas, neste tipo de cultivo, pois podem induzir formação de calos; exceção feita para embriões jovens de algumas espécies de cafeeiro (Jesus et $a l ., 2010)$. Neste trabalho, objetivou-se avaliar a relação entre o estádio de desenvolvimento do fruto de cafeeiro e a concentração de sacarose no meio, para o desenvolvimento in vitro de embriões do cv. Acaiá.

\section{MATERIAL E MÉTODOS}

Foram coletados frutos de Coffea arabica cv. Acaiá, em diferentes estádios de desenvolvimento (chumbinho, chumbo, verde, verde-cana, cereja e passa). Após colhidos, os frutos foram lavados, desinfestados, com álcool $70 \%$, durante um minuto, hipoclorito de sódio $2 \%$, durante 15 minutos, e enxaguados três vezes com água destilada, autoclavada em câmara de fluxo laminar.

Com auxílio de lupa, bisturi e pinça, os embriões foram excisados e inoculados individualmente em tubos de ensaio, contendo $15 \mathrm{~mL}$ do meio de cultura MS, acrescido de diferentes concentrações de sacarose $(0,15,30,60,90$ e $120 \mathrm{~g} \mathrm{~L}^{-1}$ ), com pH ajustado para 5,8, solidificado com 6 $\mathrm{g} \mathrm{L}^{-1}$ de ágar e autoclavado a $121^{\circ} \mathrm{C}, 1,2$ atm, durante 20 
minutos. Os tratamentos consistiram em combinação das diferentes concentrações de sacarose e dos estádios de desenvolvimento dos frutos.

Os embriões, após inoculação, foram transferidos para sala de crescimento, com temperatura de $27 \pm 1{ }^{\circ} \mathrm{C}$, fotoperíodo de 16 horas e $35 \mu \mathrm{mol} \mathrm{m} \mathrm{m}^{-2} \mathrm{~s}^{-1}$ de intensidade luminosa. $\mathrm{O}$ delineamento experimental utilizado foi inteiramente casualizado, em esquema fatorial $6 \times 6$, com seis repetições constituídas por quatro tubos cada. As avaliações foram realizadas após 60 dias da inoculação. As características avaliadas foram: massa da matéria fresca total (g), massa da matéria fresca do sistema radicular (g), massa da matéria fresca da parte aérea (g) [realizados em balança digital] e comprimento da parte aérea ( $\mathrm{mm})$. Os dados coletados foram submetidos a teste de variância, sendo utilizado o software Sisvar (Ferreira, 2000) e teste de médias F, com $1 \%$ de significância.

\section{RESULTADOS E DISCUSSÃO}

A germinação in vitro dos embriões ocorreu em $100 \%$ dos tratamentos analisados. O resumo das análises de variância para as características comprimento da parte aérea, massa da matéria fresca total, massa da matéria fresca do sistema radicular e massa da matéria fresca da parte aérea encontra-se na Tabela 1.

Observou-se, pelas avaliações, que a interação sacarose $\mathrm{X}$ estádios de desenvolvimento dos frutos foi significativa para todas as características estudadas. Para massa da matéria fresca total das plântulas (Figura 1), resultados positivos foram obtidos quando se adicionou ao meio de cultura $55 \mathrm{~g} \mathrm{~L}^{-1}$ de sacarose, para embriões no estádio verde, com massa de 0,20 g. Quando a concentração de sacarose foi aumentada progressivamente, as concentrações acima de $60 \mathrm{~g} \mathrm{~L}^{-1}$ provocaram redução na massa de matéria fresca total das plântulas, em todos os estádios de desenvolvimento do fruto.

Na maior parte dos estádios de desenvolvimento do fruto utilizados nesse experimento, para o tratamento sem adição de sacarose obteve-se reduzido ganho de massa de matéria fresca total das plântulas, atestando o fato de que o embrião pode até germinar na ausência de uma fonte de carbono, porém, para o seu posterior crescimento é necessária a suplementação do meio com uma fonte de energia. Em tratamentos sem adição de sacarose, o ganho total das plântulas foi afetado, mostrando que o carbono é fonte essencial a ser adicionada no meio de cultivo.

No entanto, concentrações mais elevadas de sacarose reduziram a massa da matéria fresca total, possivelmente pelo aumento do potencial osmótico do meio, dificultando a absorção de sais e de água pelas plântulas. Segundo Kozai \& Nguyen (2003), a presença de fontes externas de carbono para o explante desfavorece o desenvolvimento de autotrofia das plântulas, diminuindo o crescimento e podendo levar as plântulas à morte, durante a aclimatização, pela falta de fotossíntese.

Existem autores, porém, contrários à ideia de redução de sacarose durante a micropropagação, que afirmam que

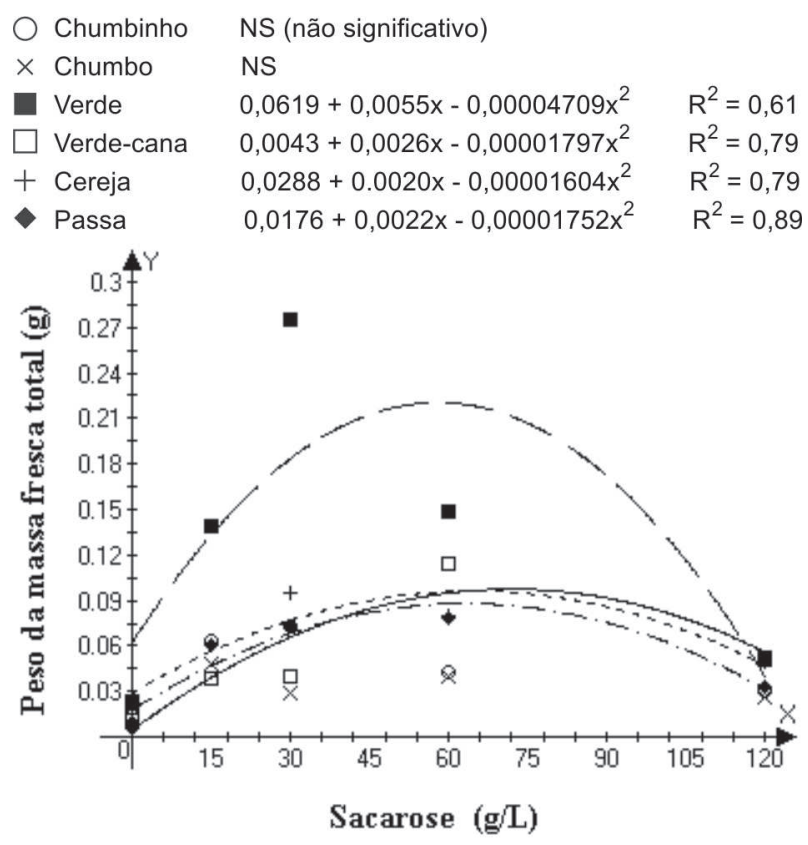

Figura 1. Peso total da matéria fresca de plântulas de cafeeiro 'Acaiá' oriundas de embriões zigóticos retirados de frutos em diferentes estádios de desenvolvimento e cultivados em meio de cultura com diferentes concentrações de sacarose.

Tabela 1. Resumo das análises de variância para as características comprimento da parte aérea (CPA), massa da matéria fresca total (MMFT), massa da matéria fresca do sistema radicular (MMFSR) e massa da matéria fresca da parte aérea (MMFPA)

\begin{tabular}{|c|c|c|c|c|c|}
\hline \multirow{2}{*}{ FV } & \multirow{2}{*}{ GL } & \multicolumn{4}{|c|}{ Quadrados Médios } \\
\hline & & CPA & MMFT & MMFSR & MMFPA \\
\hline Sacarose & 4 & $5,3810 * *$ & $0,017782 * *$ & $0,000904 * *$ & $0,013043^{* *}$ \\
\hline Estádios & 5 & $1,9811 * *$ & $0,012663 * *$ & $0,00624 * *$ & $0,009538 * *$ \\
\hline E. $x \mathrm{~S}$. & 20 & $0,3611 * *$ & $0,003432 * *$ & $0,00183^{* *}$ & $0,00693 * *$ \\
\hline Erro & 150 & $0,0581 * *$ & $0,000742 * *$ & $0,000021 * *$ & $0,00693 * *$ \\
\hline Total & 179 & & & & \\
\hline$\overline{\mathrm{CV} \%}$ & & 14,41 & 3,64 & 0,65 & 3,54 \\
\hline
\end{tabular}


os níveis de sacarose devem ser mantidos em torno de 30 $\mathrm{g} \mathrm{L}^{-1}$ na fase que antecede a aclimatização, para a planta acumular reservas e enfrentar o meio ambiente (Capellades et al., 1991). Andrade et al. (2001), estudando a resposta de embriões de Coffea arabica e C. canephora, observaram que a eficiente germinação e desenvolvimento das plântulas ocorreu em meio de cultivo MS que continha 30 $\mathrm{g} \mathrm{L}^{-1}$ de sacarose.

A melhor concentração de sacarose, avaliada para parte aérea das plântulas, foi de $58,3 \mathrm{~g} \mathrm{~L}^{-1}$ para embriões de fruto no estádio verde, promovendo seu maior desenvolvimento (Figura 2).

Melhores respostas foram verificadas com concentrações de sacarose variando entre 51 e $70 \mathrm{~g} \mathrm{~L}^{-1}$, comprovando o fato de que, quanto mais jovem o embrião, maior deve ser a osmolaridade do meio de cultura. Normalmente, $60 \mathrm{~g} \mathrm{~L}^{-1}$ de sacarose tem sido indicada como a concentração ótima para a cultura de embriões imaturos.

Pereira et al. (2006) verificaram, em embriões de palmeira murmuru (Astrocaryum ulei Burret), que a concentração de $15 \mathrm{~g} \mathrm{~L}^{-1}$ de sacarose para embriões obtidos de frutos maduros foi suficiente para que se alcançassem os melhores índices de germinação. Estes resultados confirmam a hipótese de que, dependendo da espécie e do estádio de desenvolvimento dos embriões, com presença de carboidratos no meio de cultura, mesmo que em concentrações mínimas ou na sua ausência, embriões de muitas espécies utilizam a energia necessária para a germinação, in vitro, a partir de suas próprias reservas.
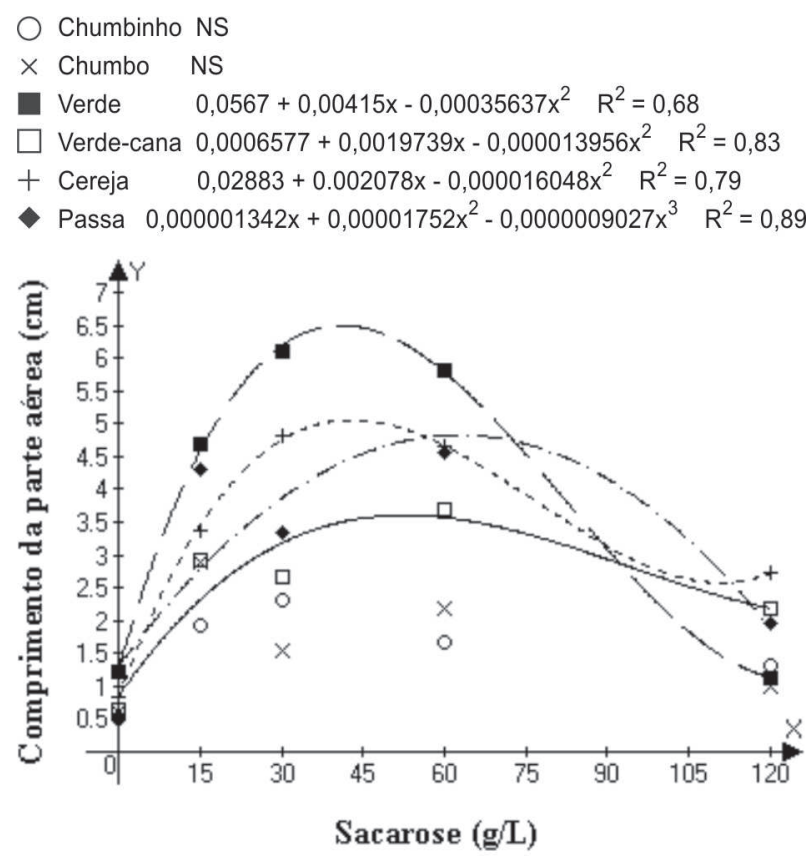

Figura 2. Comprimento de plântulas de cafeeiro 'Acaiá' oriundas de embriões zigóticos retirados de frutos em diferentes estádios de desenvolvimento e cultivados em meio de cultura com diferentes concentrações de sacarose.
Em cafeeiros, Ribeiro et al. (2003) obtiveram êxito com o cultivo in vitro de embriões de frutos no estádio verdecana, cultivados em meio MS, com $30 \mathrm{~g} \mathrm{~L}^{-1}$ de sacarose no meio. Se o meio estiver deficiente ou abaixo dessa concentração de sacarose, formam-se plântulas disformes, com baixa probabilidade de sobrevivência, ou não germinam os embriões.

Observou-se que as plântulas apresentaram máximo desenvolvimento até um limite de concentração de sacarose, após o qual houve redução nos parâmetros avaliados. Esse comportamento foi provavelmente causado por aumento excessivo do potencial osmótico do meio.

Os piores resultados foram observados nos estádios chumbinho e chumbo, justamente os mais precoces, indicando que, provavelmente, os embriões não apresentavam condições para se desenvolverem, em um meio de cultivo sem aminoácidos e vitaminas. À medida que o embrião zigótico desenvolve-se, ocorrem mudanças progressivas nas suas exigências nutricionais, passando de heterotróficas para autotróficas. A distinção entre estas duas fases baseia-se na dependência do embrião pelas substâncias nutritivas armazenadas no endosperma.

Inicialmente, o zigoto e o embrião, nas fases subsequentes à fecundação, possuem pouca capacidade de síntese e se utilizam das reservas nutricionais, fito-hormônios e outros metabólitos essenciais presentes no endosperma e células acessórias do saco embrionário (Raghavan, 1976). Ainda no estádio globular, o embrião continua sendo heterotrófico. A precocidade dos embriões também pode ser determinante, na hora da sua retirada da semente, por serem mais frágeis e mais susceptíveis a danos físicos (Raghavan, 1976).

Os melhores resultados foram obtidos no estádio verde do fruto do cafeeiro, estando o embrião em estádio cordiforme final. Portanto, somente a partir desse estádio, com início do desenvolvimento dos cotilédones, é que o embrião começa a tornar-se independente e autotrófico. Segundo Pereira et al. (2007), as concentrações mais apropriadas de sacarose que devem ser adicionadas ao meio de cultivo variam com a espécie, com o ambiente nos quais serão mantidos os frascos, com o estádio da micropropagação e com a possibilidade de fornecerem-se outras fontes de carbono aos explantes.

Para a massa da matéria fresca do sistema radicular, observou-se, pela análise das curvas de regressão, que a melhor resposta ocorreu com a concentração de $70 \mathrm{~g} \mathrm{~L}^{-1}$ de sacarose, em embriões de frutos no estádio verde e massa de 0,045 g (Figura 3). Comportamento semelhante foi observado por Dignart et al. (2009), no cultivo de embriões de orquídea Cattleya walkeriana, em que se verificou formação de raízes, relacionada com aumento da 
concentração de sacarose, e que o nível de $30 \%$ de sacarose era visivelmente mais eficiente do que o nível de $15 \%$, para a melhor formação de raízes.

Grattapaglia \& Machado (2004) afirmaram que a disponibilidade de uma fonte de energia é indispensável para que ocorra a rizogênese e ressaltam que a concentração de sacarose no meio de cultura deve ser mantida entre 2 e $3 \%$. De acordo com a Figura 3 , concentrações acima de 70 $\mathrm{g} \mathrm{L}^{-1}$ contribuíram para o decréscimo da massa de matéria fresca do sistema radicular das plântulas analisadas.

Quando foi avaliada a massa de matéria fresca da parte aérea (Figura 4), resultado semelhante ao anterior foi obtido, verificando-se melhor resposta em 51,25 $\mathrm{g} \mathrm{L}^{-1} \mathrm{de}$ sacarose, para embriões de fruto no estádio verde. Concentrações crescentes de sacarose resultaram em decréscimo no desenvolvimento das plântulas e, como consequência, a redução da massa de matéria fresca da parte aérea.

Torres et al. (2005), cultivando embriões de helicônia (Heliconia rostrata Ruiz \& Pav.), verificaram que melhores respostas para desenvolvimento da parte aérea das plântulas foram obtidas nos tratamentos com meio de cultura MS, suplementado com 3\% de sacarose. Em concentrações acima de $6 \%$, reduziu-se a percentagem de plântulas formadas para 5,9\%. Concentrações ainda maiores, de 9 a $12 \%$, inibiram a germinação dos embriões, possivelmente pela queda do potencial osmótico do meio de cultivo.

Rietsema et al. (1953) mostraram a importância da osmolaridade do meio sobre o crescimento dos embriões

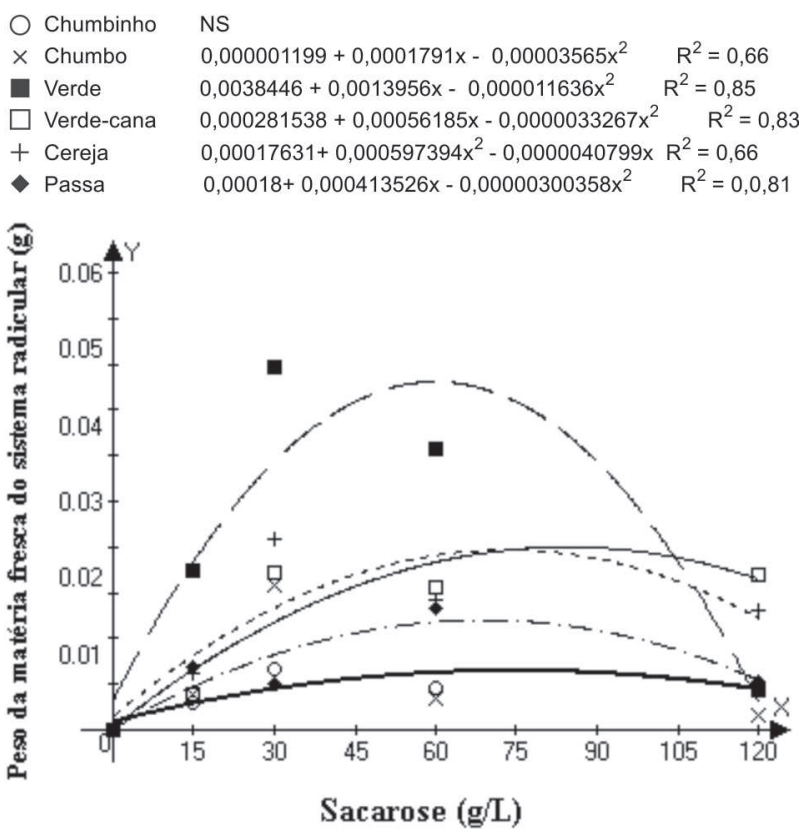

Figura 3. Peso da matéria fresca do sistema radicular de plântulas de cafeeiro 'Acaiá' oriundas de embriões zigóticos retirados de frutos em diferentes estádios de desenvolvimento e cultivados em meio de cultura com diferentes concentrações de sacarose.

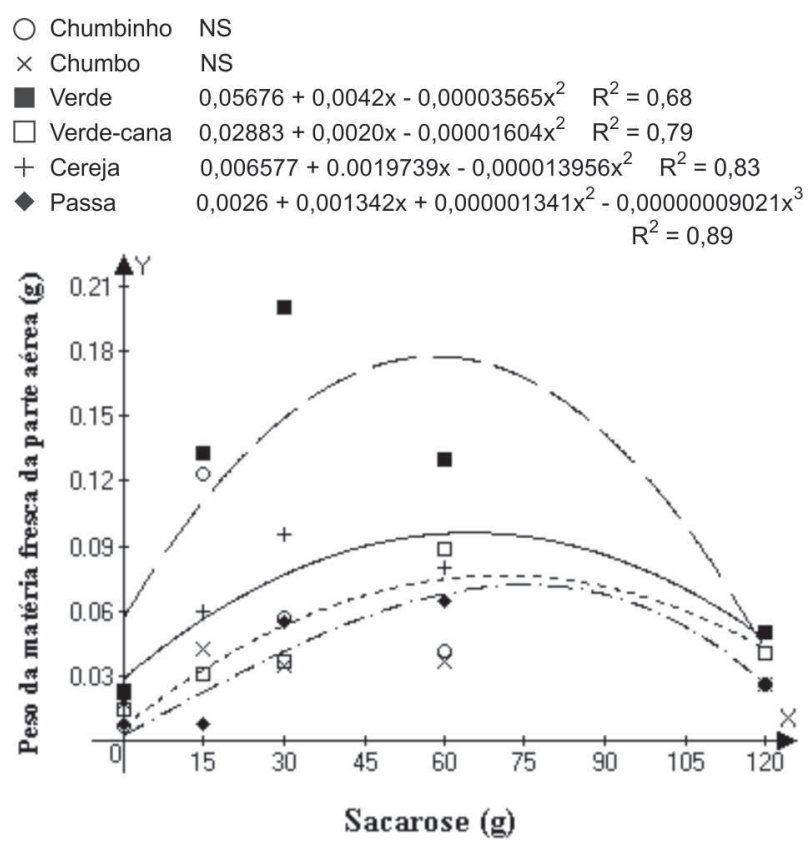

Figura 4. Peso da matéria fresca da parte aérea de plântulas de cafeeiro 'Acaiá' oriundas de embriões zigóticos retirados de frutos em diferentes estádios de desenvolvimento e cultivados em meio de cultura com diferentes concentrações de sacarose.

de Datura stramonium L., em trabalho no qual embriões maduros desenvolveram-se em meio desprovido de sacarose, enquanto aqueles em estádios precoces exigiram, progressivamente, altas concentrações de sacarose. Outros estudos com cultura de embriões têm sido realizados em cafeeiro, a fim de elucidar esta fase tão importante para a cultura de tecidos de plantas cultivadas (Morais \& Melo, 2011).

Com as respostas obtidas pelo presente experimento, fica claro que o estádio de desenvolvimento do embrião determina suas exigências nutricionais e isso é fundamental para o desenvolvimento de uma metodologia de cultura. As condições determinadas pelo trabalho fornecem, a princípio, subsídios para iniciar-se uma cultura de embriões, que podem, também ser aplicados para a cultura e regeneração de plantas a partir de embriões somáticos.

\section{CONCLUSÕES}

Há influência das concentrações de sacarose e dos estádios de desenvolvimento do fruto do cafeeiro cv. Acaiá no crescimento e desenvolvimento das plântulas in vitro.

A concentração de sacarose de 58,3 $\mathrm{g} \mathrm{L}^{-1}$, adicionada ao meio nutritivo, resulta em maior comprimento da parte aérea das plântulas oriundas de embriões excisados do fruto no estádio verde.

O estádio de desenvolvimento do embrião determina suas exigências nutricionais, de extrema importância para o desenvolvimento de futura metodologia de cultivo in vitro. 


\section{REFERÊNCIAS}

Andrade LMCO, Pasqual M, Maciel ALR, Pereira AB \& Cavalcante-Alves JM (2001) Cultivo in vitro de embriões de Coffea arabica: influência de NAA e BAP. Ciência e Agrotecnologia, 25:1063-1070.

Capellades M, Lemeur R \& Debergh P (1991) Effects of sucrose on starch accumulation and rate of photosynthesis in Rosa cultured in vitro. Plant Cell, Tissue and Organ Culture, 25:2126.

Dignart SL, Castro EM, Pasqual M, Ferronato A, Braga FT \& Paiva R (2009) Luz natural e concentrações de sacarose no cultivo in vitro de Cattleya walkeriana. Ciência e Agrotecnologia, 33:780-787.

Ferreira DF (2000) Análises estatísticas por meio do Sisvar para Windows versão 4.0. In: Reunião Anual da Região Brasileira da Sociedade Internacional de Biometria, 45, 2000, São Carlos. Anais... São Carlos, UFSCar. p.255-258.

Grattapaglia D \& Machado MA (2004) Micropropagação. In: Torres AC \& Caldas LS (Ed.) Técnicas e aplicação da cultura de tecidos de plantas. Brasília, EMBRAPA/CNPH, 2004, p.99169

Jesus MAS, Carvalho SP, Villa F, Pasqual M \& Carvalho M (2010) Desenvolvimento in vitro de brotações de cafeeiro em diferentes meios de cultura e reguladores de crescimento de planta. Scientia Agraria, 11:431-436.

Kozai T \& Nguyen QT (2003) Photoautotrophic micropropagation of woody and tropical plants. In: Jain SM \& Ishii K (Eds.) Micropropagation of woody trees and fruits. Dordrecht, Kluwer Academic. p.757-781.

Krasnyanski S, Polgar Z, Nemeth G \& Menezel L (1992) Plant regeneration for callus and protoplast of Helianthus giganteus L. Plant Cell Reports, 11:7-10.

Morais TP \& Melo B (2011) Biotecnologia aplicada ao melhoramento genético do cafeeiro. Ciência Rural, 41:753-760.

Murashige T \& Skoog F (1962) A revised medium for rapid growth and bioassays with tobacco tissue cultures. Physiologia Plantarum, 15:473-497.

Pasqual M \& Pinto JEBP (1988) Cultura de embriões. Notícias da Associação Brasileira de Cultura de Tecidos de Plantas, 9:212.
Pasqual M, Ramos JD \& Dutra LF (2001) Aplicações no melhoramento genético de plantas. Curso de Pós-Graduação 'Lato Sensu' (Especialização) à distância: Cultura de Tecidos Vegetais: Tecnologia e aplicações. Lavras, UFLA/FAEPE. 79p.

Paterson KE \& Everett NP (1985) Regeneration of Helianthus annuus inbred plants from callus. Plant Science, 42:125-132.

Pereira AR, Carvalho SP, Pasqual M \& Santos FC (2007) Embriogênese somática direta em explantes foliares de Coffea arabica cv. Acaiá Cerrado: efeito de cinetina e ácido giberélico. Ciência e Agrotecnologia, 31:332-336.

Pereira JES, Maciel TMS, Costa FHS \& Pereira MAA (2006) Germinação in vitro de embriões zigóticos de murmuru (Astrocaryum ulei). Ciência e Agrotecnologia, 30:251-256.

Raghavan V (1976) Experimental embryogenesis in vascular plants. London, Academic Press. 603p.

Revista Cafeicultura (2007) Perfil do agronegócio cafés do Brasil. Disponível em: <http://www.revistacafeicultura.com.br>. Acesso em: 17 de setembro de 2011.

Rezende JC, Ferreira EA, Pasqual M, Villa F, Botelho CE \& Carvalho SP (2008a) Development of Coffea arabica L. seedlings obtained from direct somatic embryogenesis. Coffe Science, 3:30-37

Rezende JC, Pasqual M, Carvalho SP, Pereira AR \& Villa F (2008b) Influência do meio de cultura e concentração de ágar no crescimento e desenvolvimento de plântulas de café oriundas de embriogênese somática direta. Scientia Agraria, 9:21-26.

Ribeiro LS, Pasqual M, Maciel ALR, Chagas EA \& Dutra LF (2003) Desenvolvimento in vitro de embriões zigóticos de Coffea arabica. Ciência e Agrotecnologia, Edição Especial, 27:14791483.

Rietsema J, Santinas S \& Blakeslee AF (1953) The effect of sucrose on the growth of Datura stramonium embryos in vitro. American Journal of Botany, 40:538-545.

Santos CG, Paiva R, Paiva PDO, Santana JRF \& Pereira AB (2005) Propagation of Coffea arabica c.v. acaiá cerrado through in vitro embryo culture. Plant Cell Culture and Micropropagation, $1: 19-23$.

Torres AC, Duval FD, Ribeiro DG, Barros AFF \& Aragão FAD (2005) Efeito da sacarose, cinetina, isopentenil adenina e zeatina no desenvolvimento de embriões de Heliconia rostrata in vitro. Horticultura Brasileira, 23:789-792. 